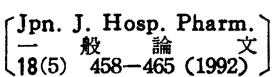

院内製剂エピネフリン・コハク酸プレドニゾロン混合吸入液の安定性 ${ }^{1}$

水島規子 $* \uparrow^{2}$, 田中祐子 $\dagger^{2}$, 藤井忠男 $\dagger^{2}$, 岩崎由雄 $\dagger^{3}$

東海大学病院薬片部 ${ }^{2}$

明治薬科大学薬剤学教室 ${ }^{3}$

\title{
Stability of a Mixed Solution of Epinephrine and Prednisolone Succinate for Inhalation Prepared in Our Hospital $\dagger^{1}$
}

\author{
NORIKO MiZUSHIMA* ${ }^{2}$, YUKO TANAKA ${ }^{2}$, \\ TADAO FUJII $\dagger^{2}$, YOSHIO IWASAKI $\dagger^{3}$ \\ Department of Pharmacy, Tokai University Hospital† ${ }^{2}$ \\ Department of Pharmaceutics, Meiji College of Pharmacy $\dagger^{3}$
}

( Received December 16, 1991)

After a mixed solution of epinephrine and prednisolone succinate for inhalation (Nebulizer No. 1 solution) was prepared in the hospital and was allocated into $50 \mathrm{ml}$ sterilized bottles, Nebulizer No. 1 solution was stored for 4 weeks under the following 3 conditions i.e. at room temperature with room lighting $\left(25 \pm 2^{\circ} \mathrm{C}, 500 \mathrm{lux}\right)$, at room temperature with prevention of room light transmittance $\left(25 \pm 2^{\circ} \mathrm{C}\right.$, covered with brown light-resistant bag), and in a cool and dark place $\left(5-10^{\circ} \mathrm{C}\right.$, covered with brown light-resistant bag). After the storage, the observation of appearances, $\mathrm{pH}$ measurement, the measurement of contents and the identification and quantification of decomposed products by high-performance liquid chromatography (HPLC) were performed.

In storage at room temperature under room lighting or prevention of room light transmittance, Nebulizer No. 1 solution was markedly colored; contents of epinephrine and prednisolone succinate in the mixed solution were decreased; and adrenochrome and prednisolone were detected as decomposed products. In cool and dark storage, there were no changes in appearances, even after storage for 4 weeks, and epinephrine and prednisolone succinate remained by $86 \%$ and $92 \%$, respectively.

Keywords—-stability; HPLC; epinephrine; prednisolone succinate; prednisolone; adrenochrome; inhalation; degradation products; color change

院内製剂エピネフリン・コハク酸プレドニゾロ

$\dagger^{1}$ 本報は, 日本薬学会第 110 年会（札幌，1990 年 8 月）にて発表.

$\dagger^{2}$ 伊勢原市下糟屋143; 143, Shimokasuya, Iseharashi, 259-11 Japan

$\dagger^{3}$ 世田谷区野沢1-35-23; 35-23, Nozawa 1-chome, Setagaya-ku, 154 Japan
ン混合吸入液（以下，ネブライザーNo. 1 液と する）は，耳鼻咽喉科でネブライザー使用時の基 本液として繁用されている.

ネブライザーは気道に湿気あるいは薬液を供給 する目的でよく用いられているものであり，圧縮 空気法, 蒸気法, 超音波法などがある. 
ネブライザー No. 1 液に配合されている注射 用コハク酸プレドニゾロンナトリウムは用時溶解 形注射剤1)であり，また一方のェピネフリンもそ の安定性は液性によるところが大きい2) ところか ら，使用時に溶解混合することが望ましい，しか し，用時溶解混合の手間を省きたいとする耳鼻咽 喉科の要望によりネブライザーNo. 1 液の名称 で院内製剤として供給している，そこで，本液の 使用期限を設定する必要があり，その安定性につ いて検討した。

試験は, 外観観察, $\mathrm{pH}$ 測定, 高速液体ク口マ トグラフィー（HPLC）による含量測定および分 解生成物の検索ならびに定量について実施した。

\section{実 験 方 法}

\section{1. 試 料}

水溶性プレドニン $50 \mathrm{mg}$ （注射用ュハク酸プレ ドニゾロンナトリゥム；コハク酸プレドニゾロン として 63.9mg 含有, Lot No. AH01，塩野義製 薬, 添付溶解液：注射用蒸留水 $5 \mathrm{ml}$ Lot No. 9801, 塩野義製薬), ボスミン液（エピネフリン 液: $500 \mathrm{ml}, 1 \mathrm{ml}$ 中エピネフリンを $1 \mathrm{mg}(0.1$ $\mathrm{w} / \mathrm{v} \%$ ) 含有，Lot No.EM21，第一製薬)，お よび注射用蒸留水 $(500 \mathrm{ml}$, Lot No. $8910 \mathrm{CS}$, 光 製薬).

\section{2. 試料液の調製}

a) ネブライザー No. 1 液

処方 水溶性プレドニン

$500 \mathrm{mg}$

ボスミン液

$16.65 \mathrm{ml}$

注射用蒸留水

適量

全量

$150 \mathrm{ml}$

無菌操作法により水溶性プレドニンを添付され ている溶解液で溶解した後, ボスミン液を加え, 注射用蒸留水で全量とし減菌びんに $50 \mathrm{ml}$ ずつ分 注し試料液とした。

b ）希釈プレドニン液

水溶性プレドニン $500 \mathrm{mg}$ を添付されている溶 解液で溶解した後, 注射用蒸留水で全量 $150 \mathrm{ml}$ と する.

c）希釈ボスミン液

ボスミン液 $16.65 \mathrm{ml}$ を注射用蒸留水で全量 150 $\mathrm{ml}$ とする.

d) 希釈ボスミン液 $(\mathrm{pH} \mathrm{6.8)}$

ボスミン液 $16.65 \mathrm{ml}$ を $1 / 30 \mathrm{M}$ リン酸緩衝夜 （pH 6.8）で全量 $150 \mathrm{ml}$ とする.

以上， b )〜 d) の液についてもネブライザー No. 1 液と同様に $50 \mathrm{ml}$ ずつ隇菌びんに分注し, 試料液とした。

\section{3. 保存条件}

隇菌びんに分注した試料液を室温室内灯下（25 $\left.\pm 2^{\circ} \mathrm{C}, 500 \mathrm{lux}\right)$, 室温遮光 $\left(25 \pm 2^{\circ} \mathrm{C}\right.$, 褐色遮光 袋), 冷所遮光 $\left(5-10^{\circ} \mathrm{C}\right.$, 褐色遮光袋) の 3 条件 に保存した。

\section{4. 外観観察および $\mathbf{p H}$ 測定}

試料液の色調の変化, 混濁の有無について肉眼 で観察した後，pH 測定を行った。 $\mathrm{pH}$ 測定は日 立一堀場 $\mathrm{pH}$ メーター F-7 型を用いた。

\section{HPLC による含量測定と分解物の検索}

I ）標準品および分解生成物の標品

コハク酸プレドニゾロン（Lot No. 86C-0149, シグマ社)，プレドニゾロン（Lot No.9628356, メルク社), L-エピネフリン (Lot No. LTQ7494, 和光純薬)，アドレノクロム (Lot No.127F0870, シグマ社)

II）分析条件 I

装置：TRIROTAR-V，UVIDEC-100-IV(日 本分光). 検出波長 : $242 \mathrm{~nm}$ (0.02AUFS). カラ ム：マイクロボンダパック C18（ウォーターズ, $3.9 \mathrm{~mm} \times 300 \mathrm{~mm})$. 移動相: 水 (酶酸 $\mathrm{pH} 3.45)$, メタノール $(9: 11)$. 流速 $: 1.0 \mathrm{ml} / \mathrm{min}$. 試料注 入量 : $10 \mu 1$.

III）分析条件 II

装置：TRIROTAR-V， UVIDEC-100-IV， FP-210 (日本分光). 検出: UV $300 \mathrm{~nm}(0.02$ AUFS), 螢光検出励起 (EX) $285 \mathrm{~nm}$ 螢光 (EM) $340 \mathrm{~nm}(\mathrm{ATT} \times 8)$.カラム：マイクロボンダパッ ク $\mathrm{C} 18$ (ウォーターズ, $3.9 \mathrm{~mm} \times 300 \mathrm{~mm}$ ). 移動 相：リン酸を用いて pH 2.35 に調整した $10 \mathrm{mM}$ リン酸ナトリウム緩衝液に $1 \mathrm{mM} 1$ 1-オクタンスル ホン酸ナトリウムと $10 \mathrm{mM}$ 硫酸ナトリウムを添 加した液, メタノール $(95: 5)$. 流速 $: 1.0 \mathrm{ml} /$ min. 試料注入量 : $10 \mu 1$. 
HPLC 条件Iにより試料液中のコハク酸プレ ドニゾロンの含量測定と同時にコハク酸プレドニ ゾロンの分解物であるプレドニゾロンの定量を行 い, HPLC 条件Iにより試料液中のエピネフリ ンの含量測定と同時にェピネフリンの分解物であ るアドレノクロムの定量を行った。エピネフリン の含量測定には螢光検出を，アドレノクロムの定 量には UV 検出を用いた。

\section{結 果と考察}

\section{1. 外観変化および $\mathbf{p H}$ 変化}

ネブライザー No. 1 液および比較対照のため の各種試料液の外観観察と $\mathrm{pH}$ 測定結果を Table 1 に示す.

ネブライザー No. 1 液拈よび各種試料液は調 製時無色透明であり, 冷所保存においては経時外 観変化および $\mathrm{pH}$ 変化いずれも認められなかっ た. ネブライザー No. 1 液は室温室内灯下保存 で 2 日後より, また室温遮光保存で 5 日後より着 色が認められた。この着色は希釈ボスミン液 $(\mathrm{pH}$ 6.8)に打いても同様に認められたこと, 低 $\mathrm{pH}$ 示す希釈ボスミン液扣よび希釈プレドニン液では みられないことより，エピネフリンの $\mathrm{pH}$ に依存
する変化であると考えられる。

また，ネブライザーNo. 1 液は 3 週間保存後 より沈殿物の生成がみとめられたが, 希釈プレド ニン液, 希釈ボスミン液（pH 6.8）でも認めら れ，コハク酸プレドニゾロン，エピネフリンのそ れぞれの分解によるものと考えられる.

ネブライザー No. 1 液の調製時における $\mathrm{pH}$ は6.80で，水溶性プレドニンに添加されているリ ン酸ナトリウムの緩衝能により希瀵プレドニン液 と類似の $\mathrm{pH}$ を示するのと考えられる.ネブライ ザーNo. 1 液と希釈プレドニン液は室温室内灯 下拉よび室温遮光保存においてやや $\mathrm{pH}$ 低下の傾 向が認められた.

\section{HPLC による分離定量}

HPLC 条件 I におけるコハク酸プレドニゾロ ンとプレドニゾロンの標品のクロマトグラムおよ び検量線を Fig. 1 に示す.

それぞれの溶出時間はコハク酸プレドニゾロン 10分, プレドニゾロン 8 分であり，いずれも良好 な分離を示し，ピーク高さを用いた検量線の相関 係数 $\mathbf{r}$ はコハク酸プレドニゾロン： $\mathrm{r}=0.997$ ( $\mathrm{n}$ =8), プレドニゾロン: $\mathrm{r}=0.999(\mathrm{n}=8)$ を示し, 原点を通る良好な直線性を示すものであった。

Table 1. Changes of $\mathrm{pH}$ and Appearance during Storage

\begin{tabular}{|c|c|c|c|c|c|c|c|c|c|}
\hline \multirow{2}{*}{$\begin{array}{l} \\
\text { Storage } \\
\text { condition } \\
\end{array}$} & \multirow{2}{*}{$\begin{array}{l}\text { Time } \\
\text { (day) }\end{array}$} & \multicolumn{2}{|c|}{$\begin{array}{l}\text { Nebulizer No.1 } \\
\text { Solution }\end{array}$} & \multicolumn{2}{|c|}{$\begin{array}{l}\text { Diluted Predonine } \\
\text { Solution }\end{array}$} & \multicolumn{2}{|c|}{$\begin{array}{l}\text { Diluted Bosmin } \\
\text { Solution }\end{array}$} & \multicolumn{2}{|c|}{$\begin{array}{l}\text { Diluted Bosmin } \\
\text { Solution (pH6.8) }\end{array}$} \\
\hline & & $\mathrm{pH}$ & Appearance & $\mathrm{pH}$ & Appearance & $\mathrm{pH}$ & Appearance & $\mathrm{pH}$ & Appearance \\
\hline & 0 & 6.80 & Colorless & 6.96 & Colorless & 3.42 & Colorless & 6.73 & Colorless \\
\hline $5-10^{\circ} \mathrm{C}$ & 7 & 6.76 & -a) & 6.89 & - & 3.45 & - & 6.70 & - \\
\hline Prevention & 14 & 6.70 & - & 6.87 & - & 3.57 & - & 6.72 & - \\
\hline \multirow[t]{2}{*}{ of light } & 21 & 6.75 & - & 6.92 & - & 3.50 & - & 6.70 & - \\
\hline & 28 & 6.72 & - & 6.84 & - & 3.55 & - & 6.74 & - \\
\hline $25 \pm 2^{\circ} \mathrm{C}$ & 7 & 6.60 & Brown & 6.82 & - & 3.40 & - & 6.68 & Brown \\
\hline Prevention & 14 & 6.30 & Brown & 6.70 & - & 3.50 & - & 6.64 & Brown \\
\hline \multirow[t]{2}{*}{ of light } & 21 & 6.23 & Brown, ppt. ${ }^{\text {b) }}$ & 6.68 & Colorless, ppt. & 3.50 & - & 6.63 & Brown, ppt. \\
\hline & 28 & 6.36 & Brown, ppt. & 6.56 & Colorless, ppt. & 3.54 & - & 6.60 & Brown, ppt. \\
\hline $25 \pm 2^{\circ} \mathrm{C}$ & 7 & 6.53 & Brown & 6.79 & - & 3.36 & - & 6.68 & Brown \\
\hline Under the & 14 & 6.28 & Brown & 6.69 & - & 3.40 & - & 6.65 & Brown \\
\hline light & 21 & 6.21 & Brown, ppt. & 6.67 & Colorless, ppt. & 3.30 & - & 6.63 & Brown, ppt. \\
\hline (500lux) & 28 & 6.38 & Brown, ppt. & 6.56 & Colorless, ppt. & 3.32 & - & 6.60 & Brown, ppt. \\
\hline
\end{tabular}

a) - : No Change, b) ppt.: Precipitate 

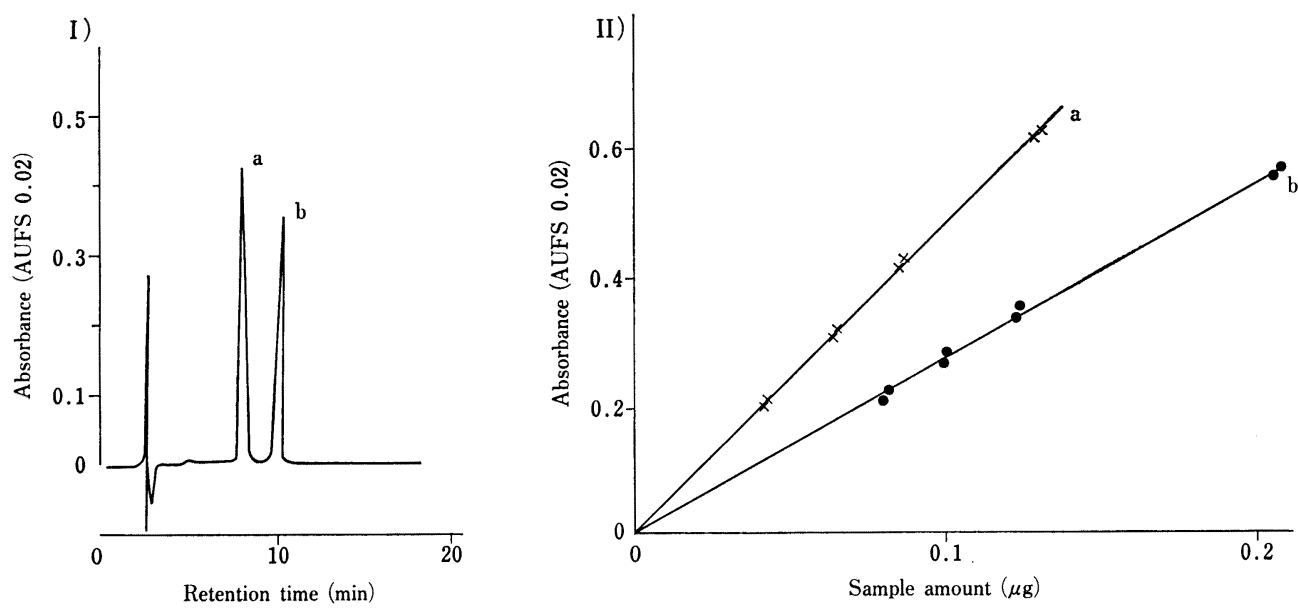

Fig. 1. HPLC Chromatograms and Calibration Curves of Compounds in Condition I

I) HPLC Chromatograms

a : Prednisolone $0.086 \mu \mathrm{g} \quad \mathrm{b}$ : Prednisolone succinate $0.124 \mu \mathrm{g}$

II) Calibration Curves by HPLC
a : Prednisolone
$\mathrm{b}$ : Prednisolone succinate

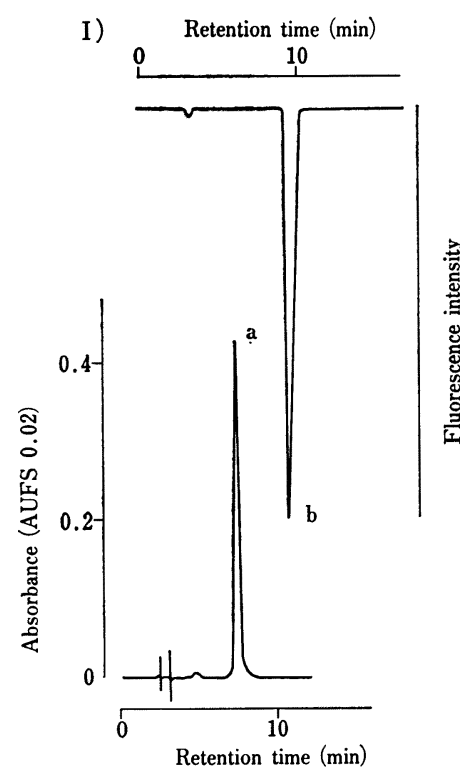

.II)
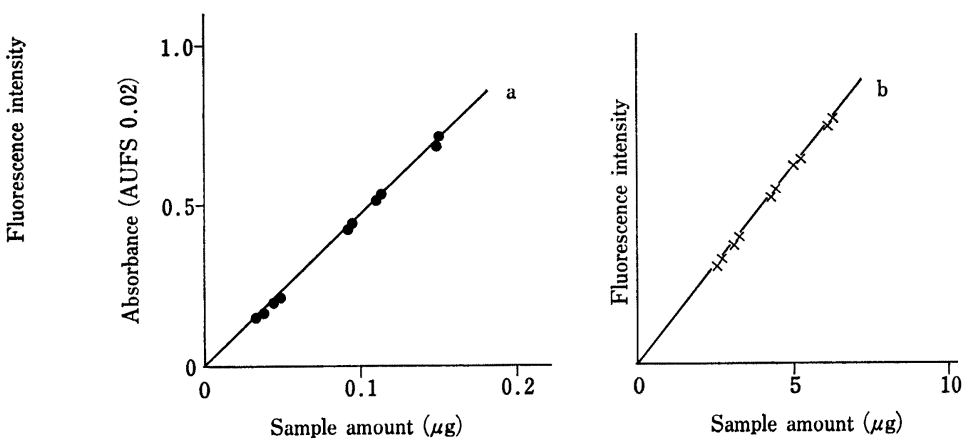

Fig. 2. HPLC Chromatograms and Calibration Curves of Compounds in Condition II

I) HPLC Chromatograms

a : Adrenochrome $0.094 \mu \mathrm{g}$

$\mathrm{b}: 1$-Epinephrine $5.2 \mu \mathrm{g}$

II) Calibration Curves by HPLC
a : Adrenochrome
$\mathrm{b}:$ 1-Epinephrine

HPLC 条件IIにおけるエビネフリンとアドレ， クロムの標品のクロマトグラムおよび検量線を

Fig. 2 に示す.
溶出時問はエピネフリン 9.6 分, アドレノクロ ム 7.8 分であり良好な分離が得られピーク高さを 用いた検量線の相関係数 $\mathrm{r}$ は, エピネフリン： 
$r=0.999(n=10), \quad$ アドレノクロム $: r=0.999$ （n=10）を示し，原点を通る良好な直線性を示す ものであった．試料液中のエピネフリンと分解生 成物アドレノクロムを同一希釈液で同時定量する ため, 䖝光検出を低感度で UV 検出を高感度で 用いた。

\section{3. ネブライザー No. 1 液の安定性}

ネブライザーNo. 1 液および比較対照のため の希釈プレドニン液保存後のコンク酸プレドニゾ ロンの含量変化と, 分解生成物プレドニゾロンの 生成量を Fig. 3 亿示す. 各試料液中のコハク酸 プレドニゾロンの含量は調製直後の含量を $100 \%$ として経時残存率で示し，プレドニゾロンの生成 量はコハク酸プレドニゾロンに対するモルパーセ ントで示した.

また，HPLC 条件Iに括けるネブライザー No. 1 液と希釈プレドニン液の調製時および 2 週間保存後のクロマトグラムを Fig. 4 に示す.

ネブライザーNo. 1 液, 希釈プレドニン液両 試料液中のコハク酸プレドニゾロンの含量は，室 温室内灯下保存および室温遮光保存において低下 した。

ネブライザー No. 1 液は冷所遮光保存では 4
週間後もコハク酸プレドニゾロンの残存率は $92 \%$ を示した。

分解生成物プレドニゾロンはネブライザー No. 1 液, 希釈プレドニン夜両試料液ともに調 製直後にも約 1 モルパーセント検出され，コハク 酸プレドニゾロンの含量低下に伴い増加した，両 試料液中で調製時に分解物としてプレドニゾロン の他に保持時間 7 分にプレドニゾロンと同程度の ピーク高さを示す物質 $\mathbf{x}$ が検出され，経時増加が 認められた。この物質は調製時より検出されるこ と，保存中コハク酸プレドニゾロンの含量低下に 伴い生成するプレドニゾロンとともに増加してい ることより，コハク酸プレドニン゙ロンの分解物で あると考えられるが，構造を確認できなかった。

ネブライザーNo. 1 液中のコハク酸プレドニ ゾロンの含量低下, 分解物プレドニゾロンの生成 および未知分解物の生成は, 希釈プレドニン液と ほぼ同様の変化を示したことよりエピネフリ ンとの配合によるものではなく，水溶性プレドニ ン自体の溶解後の安定性によるものと考えられ る.

ネブライザー No. 1 液中および希釈ボスミン 液 (pH 6.8) ならびに希釈ボスミン液保存後のエ

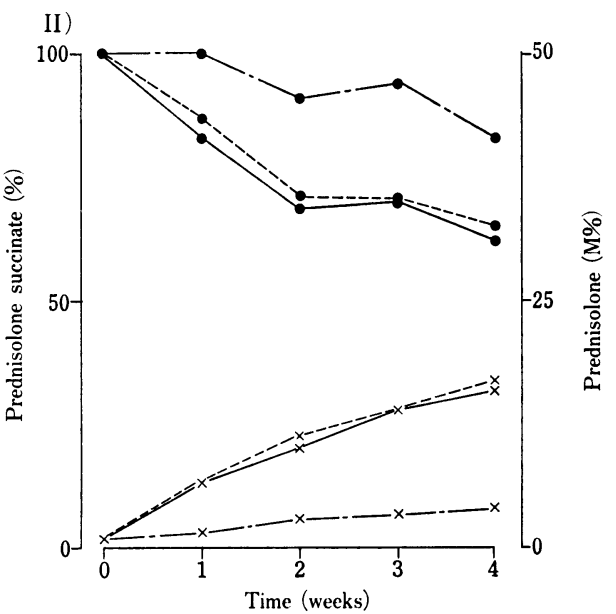

Fig. 3. Residual Amount of Prednisolone Succinate and Quantity of Prednisolone during Storage

I) Nebulizer No. 1 Solution

II) Diluted Predonine Solution

- Prednisolone succinate

$\times$ Prednisolone

- - Stored under prevention of light at $5-10^{\circ} \mathrm{C}$

- - - Stored under prevention of light at $25 \pm 2^{\circ} \mathrm{C}$

- Stored under the light $(500 \mathrm{lux})$ at $25 \pm 2^{\circ} \mathrm{C}$ 


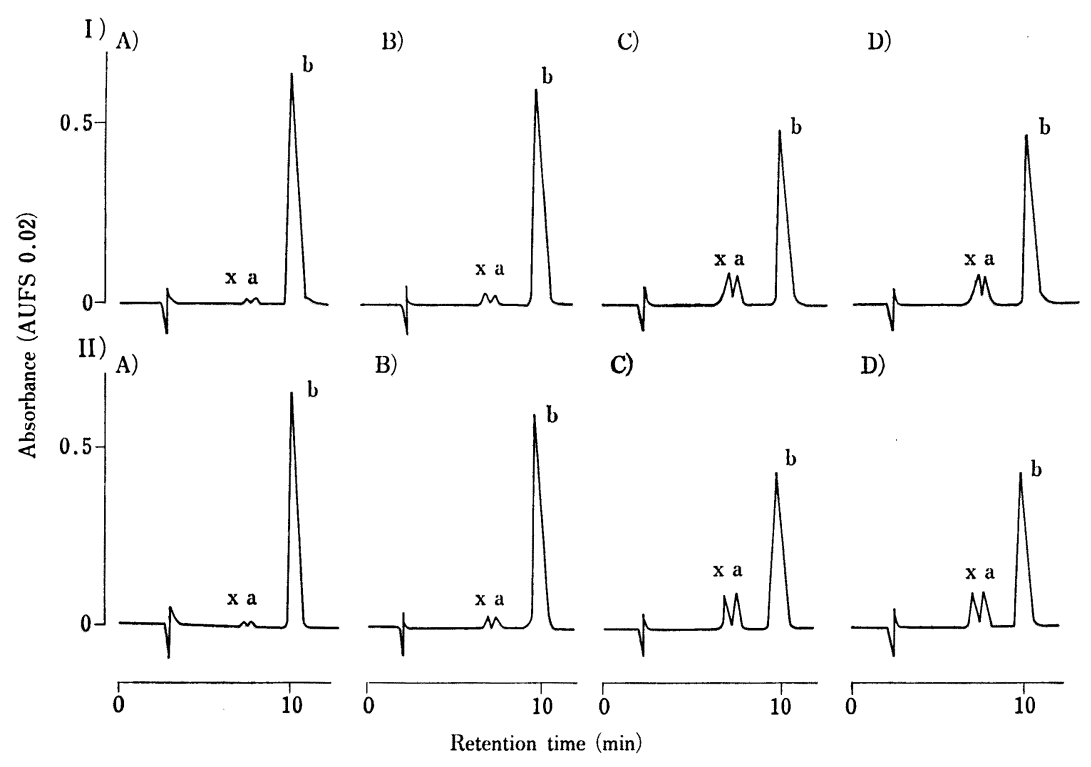

Fig. 4. HPLC Chromatugrams of Condition I

I) Nebulizer No. 1 Solution II) Diluted Predonine Solution

A) at preparation

B ) stored under prevention of light at $5-10^{\circ} \mathrm{C}$ for 2 weeks

C ) stored under prevention of light at $25 \pm 2^{\circ} \mathrm{C}$ for 2 weeks

D) stored under the light $(500 \mathrm{lux})$ at $25 \pm 2{ }^{\circ} \mathrm{C}$ for 2 weeks $\mathrm{a}$ : Prednisolone $\mathrm{b}$ : Prednisolone succinate $\mathrm{x}:$ Unknown
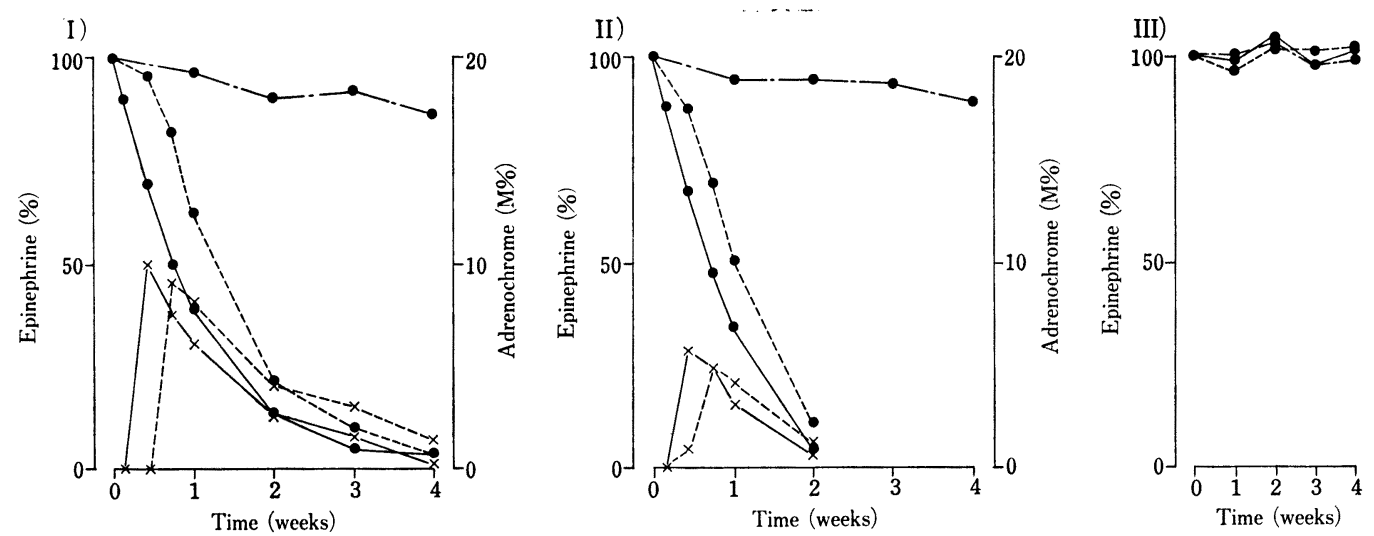

Fig. 5. Residual Amount of Epinephrine and Quantity of Adrenochrome during Storage

I) Nebulizer No. 1 Solution

II) Diluted Bosmin Solution ( $\mathrm{pH} 6.8$ )

III) Diluted Bosmin Solution

- Epinephrine $\times$ Adrenochrome

- - stored under prevention of light at $5-10^{\circ} \mathrm{C}$

- - - stored under prevention of light at $25 \pm 2^{\circ} \mathrm{C}$

- stored under the light (500 lux) at $25 \pm 2^{\circ} \mathrm{C}$ 


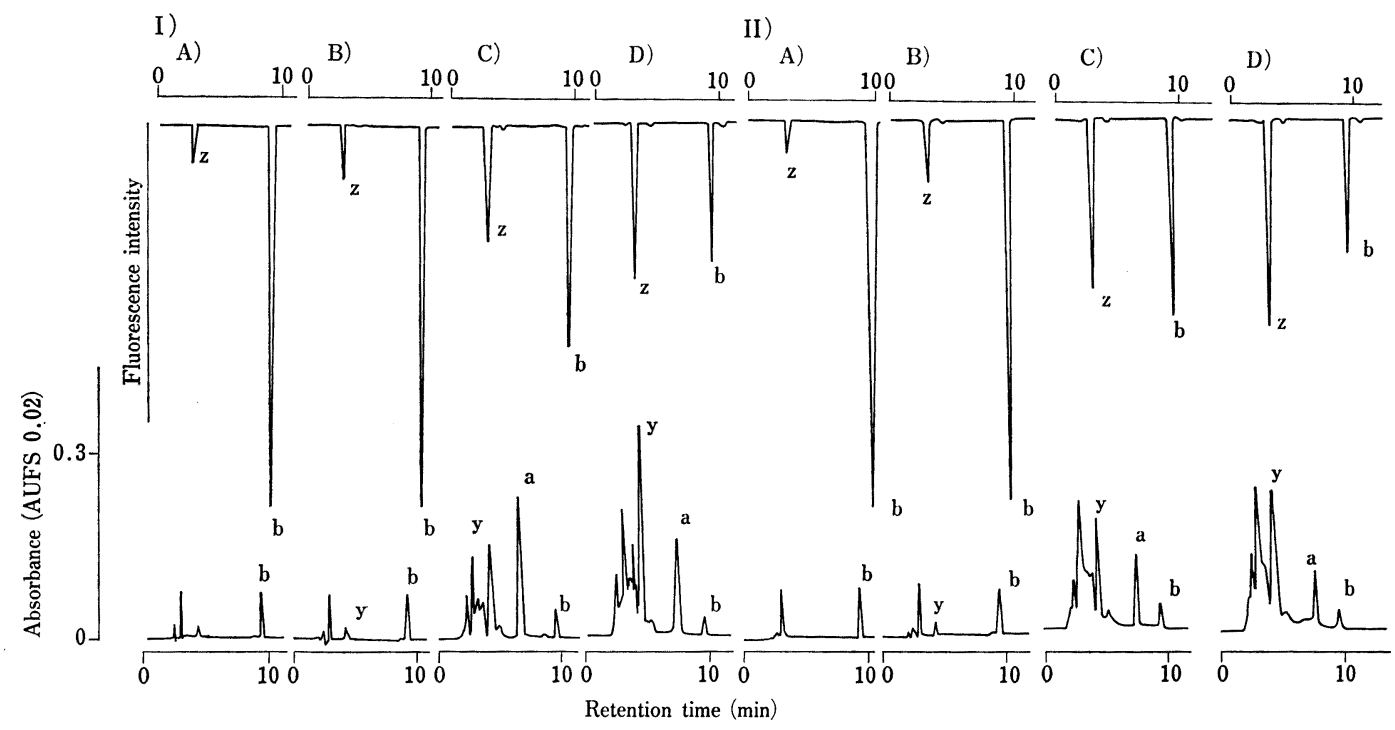

Fig. 6. HPLC Chromatograms of Condition II

I) Nebulizer No. 1 Solution II) Diluted Bosmin Solution ( $\mathrm{pH}$ 6.8)

A) at preparation

B) stored under prevention of light at $5-10^{\circ} \mathrm{C}$ for 1 week

C) stored under prevention of light at $25 \pm 2^{\circ} \mathrm{C}$ for 1 week

D) stored under the light ( $500 \mathrm{lux}$ ) at $25 \pm 2^{\circ} \mathrm{C}$ for 1 week
a : Adrenochrome
$\mathrm{b}:$ Epinephrine
$\mathrm{y}, \mathrm{z}:$ Unknown

ピネフリンの含量変化と, 分解生成物アドレノク ロムの生成量を Fig. 5 に示す. 各試料液中のエ ピネフリン含量は調製時の含量を $100 \%$ として経 時残存率で示し,アドレノクロムの生成量はエピ ネフリンに対するモルパーセントで示した.

また， HPLC 条件Iに打りるブライザー No. 1 液と $\mathrm{pH} 6.8$ の希釈ボスミン液の調製時 牤よび 1 週間保存後のクロマトグラムを Fig. 6 に示す.

ネブライザー No. 1 液中のエピネフリンの含 量変化は保存条件による影響を受け，1週間後冷 所保存では96\%であるのに対し, 室温遮光保存で $62 \%$, 室温室内灯下保存で39\% と著しい含量低下 がみられた。 希釈ボスミン液ではいずれの保存条 件でも含量低下は認められず, $\mathrm{pH} 6.8$ の希釈ボ スミン液に括いて同一 $\mathrm{pH}$ を示すネブライザー No. 1 液と同様のエピネフリンの含量低下が認 められた。 ネブライザーNo. 1 液および $\mathrm{pH} 6.8$ の希釈ボスミン液に拈いてェピネフリンの含量低
下に伴いアドレノクロムの生成が認められ，その 生成量はネブライザー No. 1 液において高い值 を示した．Fig. 5 に示すように，アドレノクロ ムは増加後減少していることから，アドレノクロ ムからさらに他の物質への分解が進んでいるもの と考えられる. Dhalla ら² は, エピネフリンの 酸化分解物としてアドレノクロムとアドレノルチ ンの生成を報告しており，アドレノルチンの生成 に対してアドレノクロムは增加後減少しているこ とから, アドレノクロムからアドレノルチンの生 成を定量的に確認している.

Fig. 6 に示すように, 分解生成物としてアド レノクロムの他に UV 検出で保持時間4.5分にy のピークが，螢光検出で保持時間 3.2 分に $z$ のピ ークが検出された． $z$ はネブライザー No. 1 夜 および pH 6.8 の希釈ボスミン液調製時より検出 され，室温保存で著しい增加を示し，また，yは 調製時にはほとんど認められなかったが，冷所保 存で 7 日後わずかに検出され，室温保存で著しい 
増加を示した.これら二つの未知物質のらち 製品ボスミン液中でも検出され，またエピネフリ ン標品にもわずかに検出された．Уはアドレノク ロム標品にもわずかに検出されること，アドレノ クロム生成減少後も増加していることより, アド レノクロムからさらに分解したアドレノルチンと 考えられ同定を試みた.アドレノルチンの標品が 得られなかったので, UV 検出器の波長を変え (220-300nm) 測定を行い, 保持時間 4.5 分を示 すピーク高さより UV スペクトルを描いたとこ ろ, この物質 $\mathrm{y}$ の UV スペクトルは Heacock ら4の報告によるアドレノルチンの UV スペクト ル $\left(\lambda_{\max }: 255,285 \mathrm{~nm} ; \lambda_{\min }: 239,272 \mathrm{~nm}\right)$ と 一致しなかっだ.

ネブライザー No. 1 液中のエピネフリン含量 低下は, 同一 $\mathrm{pH}$ に調製した $\mathrm{pH} 6.8$ の希釈ボ スミン液と同様の結果を示したが，未知分解物 $z$ は pH 6.8 の希釈ボスミン液中のほうが多く, ま たアドレノクロムおよび未知分解物 $\mathrm{y}$ はネブライ ザーNo. 1 液の方が多く検出されていることよ り, エピネフリンの液性による変化のほかに, 配 合による影響も受けているものと考えられる。未
知分解物 $\mathrm{y}, \mathrm{z}$ については, いずれも構造を推定 できなかった。

\section{結 論}

以上の結果, ネブライザー No. 1 液は, 冷所 遮光保存すれば 4 週間後も着色などの外観変化は 認められず，コハク酸プレドニゾロンの含量は92 \%であるが，エピネフリン含量は $86 \%$ に低下する こと, 温度, 光の影響により著しい分解を示すこ とを考虑し, 調製後は冷所遮光保存とし, 使用期 限を 2 週間とした。

\section{引用文献}

1）水溶性プレドニン添付文書, 塩野義製薬株式会 社; 福島跲行, 森 潔, “注射剂の配合変化”, 富士プリント，札幌，1982，pp. 424-429.

2）福島豁行, 森 潔, “注射剂の配合変化”, 富士 プリント, 札㫤, 1982, pp. 384-388 ; 加藤裕久, 古泉秀夫, 横山朋正, JJSHP, 24, 17-20 (1988).

3) K.S. Dhalla, P.K. Ganguly, H. Rupp, R.E. Beamish, N.S. Dhalla, Mol. Cell. Biochem., 87, 85 (1989).

4) R.A. Heacock, M.E.Mahon, Can. J. Chem., 36, 1550 (1958). 